\title{
Fermentation of Soybean Seeds Using Rhizopus oligosporus for Tempeh Production and Standardization Based on Isoflavones Content
}

\author{
Yohanes Dwiatmaka ${ }^{1, *}$, Endang Lukitaningsih ${ }^{2}$, Nunung Yuniarti ${ }^{2}$ and Subagus Wahyuono ${ }^{2}$ \\ 1 Faculty of Pharmacy, Sanata Dharma University, Yogyakarta, Indonesia; atma14@usd.ac.id \\ 2 Faculty of Pharmacy, Universitas Gadjah Mada, Yogyakarta, Indonesia \\ * Correspondence: atma14@usd.ac.id
}

\begin{abstract}
Tempeh is an Indonesian traditional food, made from white soybean seeds by fermentation with Rhizopus mold. Soybean seeds content high isoflavone glycosides. Isoflavones can act as phytoestrogen, antioxidant and improves memory. Isoflavone glycosides are poorly absorbed in the human body, but the aglycone isoflavones absorbed quickly. Rhizopus mold hydrolize isoflavone glycosides to be aglycone isoflavones during tempeh production. This research was aimed to know the best room temperature and time of fermentation for making soybean tempeh with high content of isoflavones. After rinsing and boiling, the soybean seeds than fermented with Rhizopus oligosporus. Three conditions were applied: (a) ambient temperature $\left(27-32^{\circ} \mathrm{C}\right.$ ) without air circulation, (b) $27 \pm 0.5^{\circ} \mathrm{C}$, and (c) $30 \pm 0.5^{\circ} \mathrm{C}$ both with air circulations. Inner temperature of tempeh was recorded hourly. Total isoflavones were measured with UV spectrophotometer every 6 hours. Based on this study, fermentation at (a) condition caused the tempeh too hot and rotted quickly. Fermentation at (b) and (c) conditions produced tempeh with good quality. Tempeh ripening was reached between $32-32$ hours with inner temperature $32-33^{\circ} \mathrm{C}$. Fermentation for 72 hours at condition (b) was chosen because its high total isoflavones content $(0.089 \% \mathrm{w} / \mathrm{w})$, but decrease about $20 \%$ compare to soybean seeds $(0.112 \% \mathrm{w} / \mathrm{w})$.
\end{abstract}

Keywords: tempeh; soybean; fermentation; Rhizopus; isoflavones

\section{Introduction}

Tempeh is an Indonesian traditional food, commonly made from white soybeans by fermentation with Rhizopus mold. Nowadays there are many kinds of seed can be processed as tempeh. Tempeh is a very nutritious food and very familiar for Indonesian people. Soybeans as the main raw material of tempeh have very good nutritional components [1]. In fact, soybean are often called "golden from the soil" because of their high, complete, and balanced of the protein content [2]. Soybean is excellent and inexpensive source of protein too [3]. In addition to nutrition content, soybeans also contain high secondary metabolites of isoflavones. Isoflavones can act as antioxidant, phytoestrogen, and improve memory [4].

The human body needs antioxidants. The environment with more pollution will increase the number of free radicals in the body, thus accelerating the deterioration, tissue damage, and cells death [5]. Free radicals trigger aging and various degenerative diseases. The antioxidant activity of soy isoflavones has good potency to reduce the damage of body cells due to exposure to free radicals.

Estrogens distributed in the body, including the central nerve. Estrogens affect cognitive abilities because they modulate the central nervous system's neurotransmitter, including acetylcholine, catecholamine, serotonin, and gamma amino butyric acid (GABA). Estrogen receptors presence in various parts that are involved in cognitive processes such as the formation of hippocampus, amygdala, and cerebral cortex, as well as learning and 
memory processes [6]. Decreasing estrogen concentration in the body, such as during menopause, causes memory loss. Estrogen replacement therapy can improve episodic and semantic memory skills. Estrogens will induce synaptogenesis in the hippocampus. Soybean seeds contain quite a lot of isoflavones, especially genistein, daidzein, and glycitein that can act as phytoestrogens. These isoflavones and some of their metabolites have agonist activity or partial agonists against estrogen receptors so they can act as weak non-steroidal estrogens [7], [8]. Isoflavones are also able to improve cognitive function through the protective mechanism of nervous system [9]. This makes it interesting to study the ability of soy products to improve memory. We need process soy products, especially tempeh with high levels of isoflavones.

In soybean seeds, there are at least 12 types of isoflavones related to genistein, daidzein, and glycitein [10]; [11]. The total content of isoflavones in dry soybeans reach $0.1-0.4 \%$ [10]. In other condition it can even reach between $0.4-9.5 \mathrm{mg} / \mathrm{g}$ or $0.04-0.95 \%$ [12]. Genistein is more dominant than other isoflavones [13]. Processing of soybeans may reduce the amount of isoflavones, but commonly people consume in the form of processed food products such as tempeh. Fermentation of soybean seeds during tempeh production reduces the non-nutritional substances and increases the content of vitamins. Fermented soybeans also serve good protein and calcium, low of saturated fat, folic acid, and sodium. Fermented soybeans have good potency of nutritious food [14]. Fermentation during process of tempeh production also hydrolyze the isoflavone glycosides to be free isoflavones (isoflavone aglycones) [15]; [16]. Aglycone isoflavones more easily absorbed in human digestive system and give effect quickly. For this reason, making a good quality of tempeh standardized of total isoflavones level is required. Total isoflavones determined using ultra violet spectrophotometer.

The process of making tempeh should be controlled to get a good quality of tempeh. Some parameters need to be considered, include the fermentation temperature, fermentation time, and content of isoflavones. Inner temperature profile of tempeh during the fermentation process was monitored to see the fermentation progress and predicted the ripening and rotting time of tempeh. The content of isoflavone aglycones was not optimal in pre-ripe tempeh. When the tempeh was overripe, decay begins to occur and unwanted metabolites such as ammonia formed. This research was aimed to determine the best room temperature and time of fermentation to get the tempeh with high content of isoflavones.

\section{Materials and Methods}

\subsection{Materials}

Soybean seeds with certificate were obtained from the Research Institute for Assorted Beans and Tubers ('BALITKABI: Balai Penelitian Tanaman Aneka Kacang dan Umbi'), Malang, East Java, Indonesia. Soybean seeds come in 5 varieties: Devon 1, Dena 1, Dega 1, Anjasmoro, and Argomulyo. Genistein (Sigma-Aldrich, USA), ethanol (Merck \& Co., Inc.), aquadest.

\subsection{Making of Soybean Tempeh}

Five varieties of soybean seeds were determined their total isoflavones content. The highest content of total isoflavones then processed as tempeh. The tempeh was made through several stages [17] with reduction of soaking time and second boiling time. Process was starting by sorting and washing the soybean seeds. The next step was first boiling for 30 minutes, then ground to break the seeds and separate the husks. The seeds were washed and soaked in fresh water for 12 hours. The next steps were second boiling for 30 minutes, then drain the water and let the seeds become warm. Soybean seeds mixed with tempeh starter (mold of Rhizopus oligosporus culture) $1 \mathrm{~g} / \mathrm{kg}$, then pour into plastic bags and flattened with a thickness of two centimeters. Sterile needle was used to perforate the plastic bags with one centimeter apart. Last step was incubate the mixture 
in incubator and let the fermentation occurred with necessary conditions. Three conditions were applied: (a) fermented at ambient temperature $\left(27-32^{\circ} \mathrm{C}\right)$ without air circulation, (b) $27 \pm 0.5{ }^{\circ} \mathrm{C}$, and (c) $30 \pm 0.5{ }^{\circ} \mathrm{C}$ both with air circulations. Inner temperature of tempeh was measured real time using Elitech ${ }^{\circledR}$ RC-4 mini temperature data logger.

\subsection{Analysis of Total Isoflavones Content}

A total $30 \mathrm{~g}$ of fresh tempeh powder was extracted with absolute ethanol to obtain $50.0 \mathrm{~mL}$ extract. Then $100 \mu \mathrm{L}$ of extract were diluted in ethanol to $10.0 \mathrm{~mL}$. For soybean powder, $50 \mu \mathrm{L}$ of extract were diluted in ethanol to $10.0 \mathrm{~mL}$. Then $3 \mathrm{~mL}$ of each solution were poured into cuvette to determine the isoflavones content. Total isoflavones were determined using UV spectrophotometer (SHIMADZU UV-1800) at $262 \mathrm{~nm}$.

\subsection{UV Scanning}

For both tempeh and soybean extracts, scanning was carried out in the range of 200 to $400 \mathrm{~nm}$ using Spectrophotometer (SHIMADZU UV-1800). Scanning was performed to obtain the spectral pattern of each material, compared to genistein spectral pattern as standard.

\section{Results}

\subsection{Total Isoflavones in Five Varieties of Soybean Seeds}

There are 5 varieties of soybean seeds selected: Devon 1, Dena 1, Dega 1, Anjasmoro, and Argomulyo. They have different of total isoflavones content. The variety with highest content of isoflavones would be processed as tempeh.

Table 1. Total isoflavones content in 5 varieties of soybean seeds.

\begin{tabular}{ccc}
\hline $\begin{array}{c}\text { Soybean } \\
\text { varieties }\end{array}$ & $\begin{array}{c}\text { Isoflavon content* } \\
(\% \mathbf{~ w} / \mathbf{w})\end{array}$ & Rank \\
\hline Devon 1 & $0.112 \pm 0.0012^{\mathrm{a}}$ & $1^{* *}$ \\
Dena 1 & $0.062 \pm 0.0009^{\mathrm{e}}$ & 5 \\
Dega 1 & $0.092 \pm 0.0011^{\mathrm{b}}$ & 2 \\
Anjasmoro & $0.068 \pm 0.0009^{\mathrm{d}}$ & 4 \\
Argomulyo & $0.074 \pm 0.0015^{\mathrm{c}}$ & 3 \\
\hline
\end{tabular}

* Means from three determinations \pm standard deviation followed by the same uppercase letter in the same column do not differ by the LSD-test at $5 \%$ significance; ${ }^{* *}$ selected for tempeh production.

As shown in table 1, variety of Devon 1 has the highest isoflavones content, followed by Dega 1, Argomulyo, Anjasmoro and Dena 1. The isoflavones content were significantly different $(\mathrm{p}<0.05)$.

\subsection{Fermentation Process}

Without good air circulation, fermentation at ambient temperature $27-32{ }^{\circ} \mathrm{C}$ (condition a) caused tempeh too hot even up to $42^{\circ} \mathrm{C}$ and rotted rapidly (Figure 1 ). At the $42^{\text {nd }}$ hour of fermentation, the tempeh showed signs of decay, marked by the smell of ammonia. 


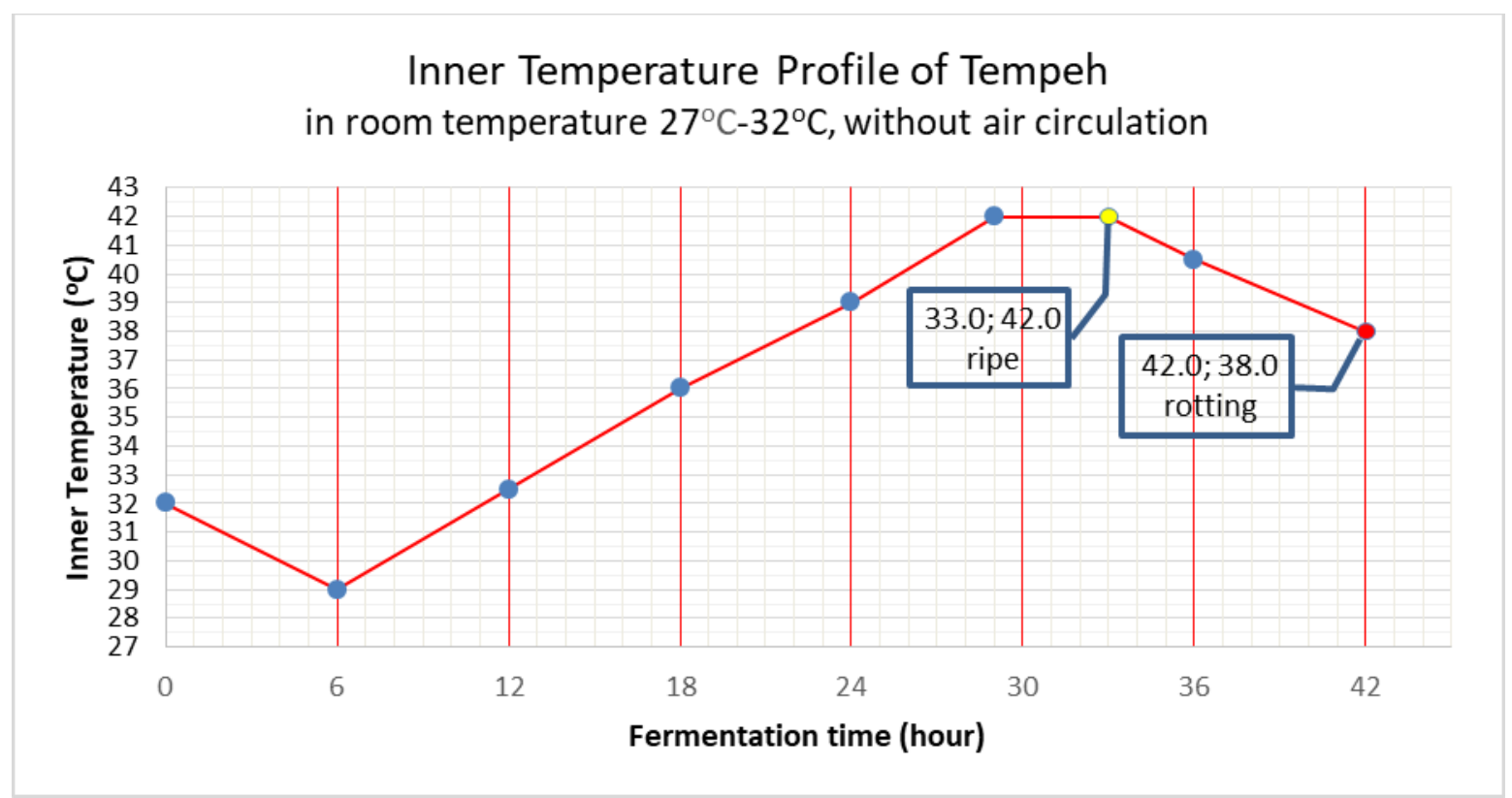

Figure 1. Inner temperature profile of tempeh during fermentation period, in ambient temperature $\left(27^{\circ} \mathrm{C}-32^{\circ} \mathrm{C}\right)$ without air circulation (condition a), sampling time every 6 hours.

When fermented at $27 \pm 0.5^{\circ} \mathrm{C}$ with good air circulation (condition $\mathrm{b}$ ), the inner peak temperature was $32.5^{\circ} \mathrm{C}$ reached at $32^{\text {nd }}$ hour as well as the time for tempeh to ripe (Figure 2). With controlled temperature and good air circulation, the inner temperature profile of tempeh has a parabolic-like pattern, especially at the time range for tempeh ripening. Rotting started at $100^{\text {th }}$ hour with inner temperature of $31.9^{\circ} \mathrm{C}$.

\section{Inner Temperature Profile of Tempeh in $27 \pm 0.5^{\circ} \mathrm{C}$, with air circulation}

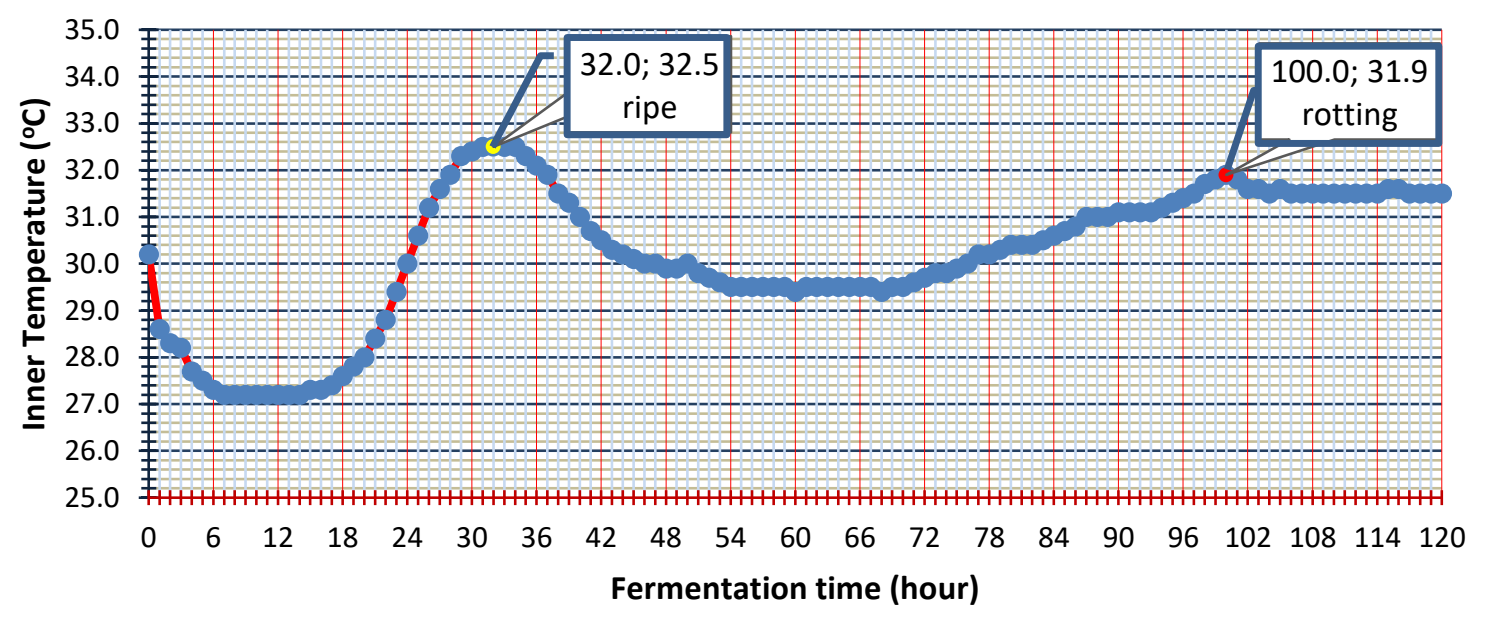

Figure 2. Inner temperature profile of tempeh during fermentation period, in $27 \pm 0.5{ }^{\circ} \mathrm{C}$ with air circulation (condition b), (sampling time hourly).

The fermentation was also carried out at $30 \pm 0.5^{\circ} \mathrm{C}$ with air circulation (Figure 3). 


\section{Inner Temperature Profile of Tempeh in $30 \pm 0.5^{\circ} \mathrm{C}$, with air circulation}

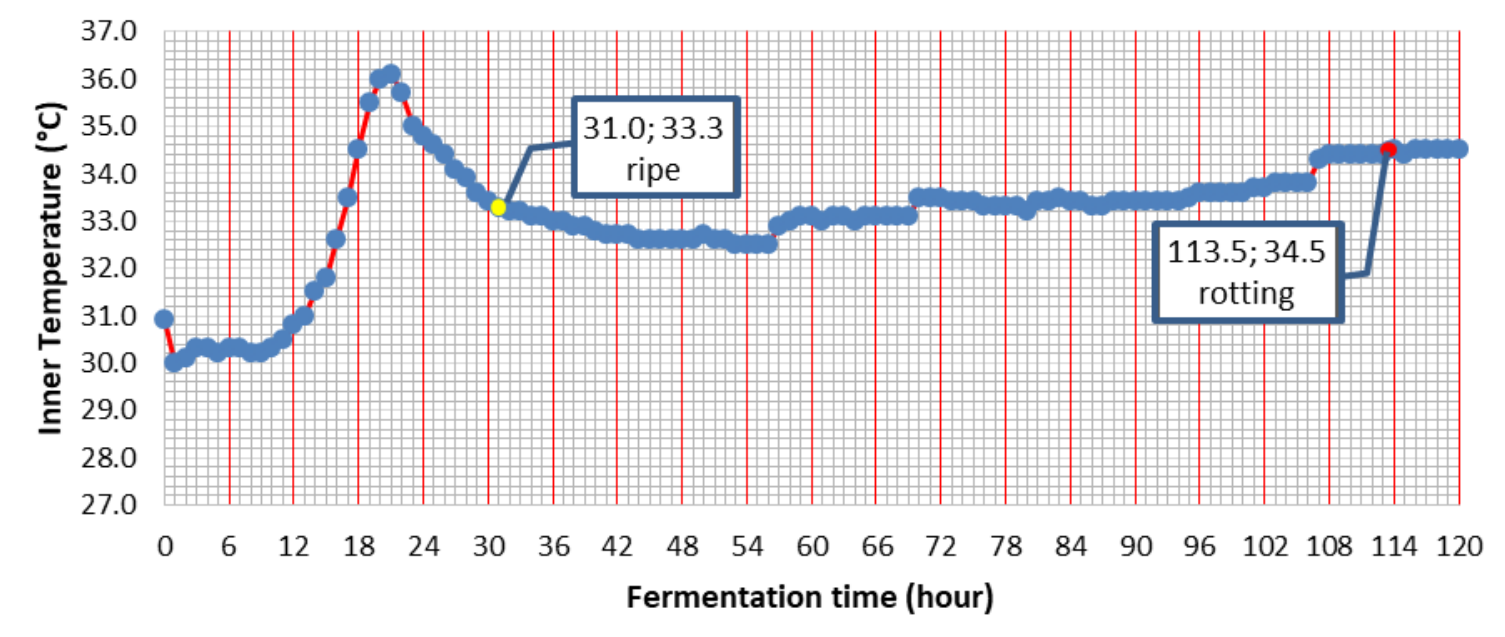

Figure 3. Inner temperature profile of tempeh during fermentation period, in $30 \pm 0.5^{\circ} \mathrm{C}$ with air circulation (condition c), sampling time hourl.

While fermented at $30 \pm 0.5^{\circ} \mathrm{C}$ (condition c), the inner peak temperature of tempeh was $36^{\circ} \mathrm{C}$ (at $22^{\text {nd }}$ hour) but the ripening occurred after the temperature drop to $33^{\circ} \mathrm{C}$ at $31^{\text {st }}$ hour. Rotting started at $113^{\text {th }}$ hour with inner temperature of $34.5^{\circ} \mathrm{C}$ (Figure 3 ). Indication of ripe tempeh was the Rhizopus covered all surface of tempeh. At that time, the tempeh would be white, clean, and good smell. When the tempeh starts to rot, the color being darker, some brown areas appear and ammonia odors smelt (figure 4).
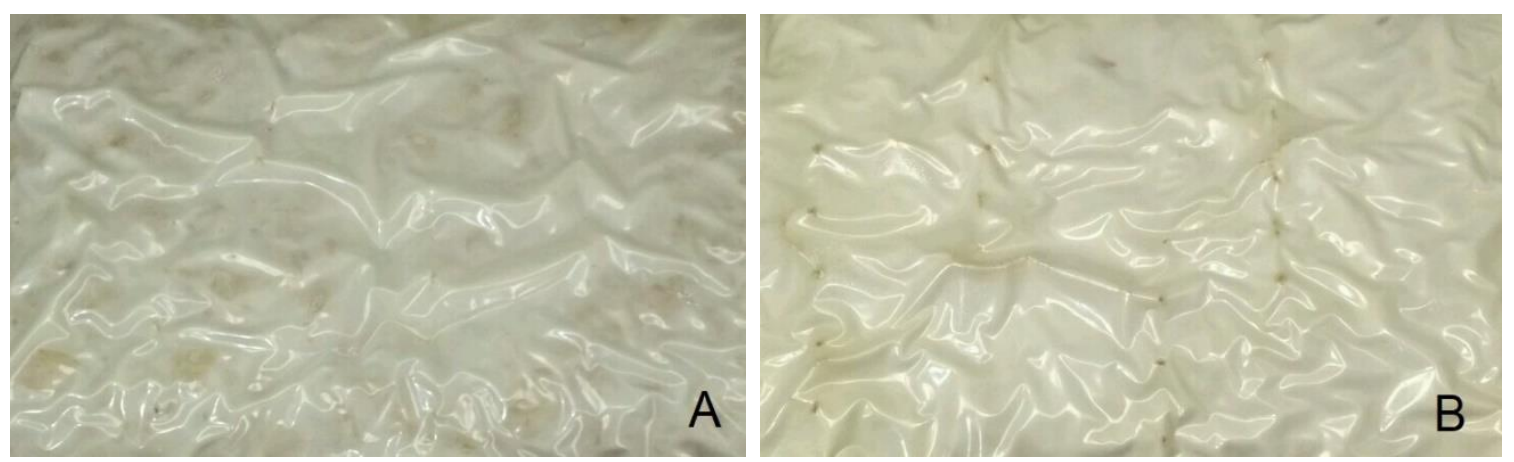

Figure 4. Tempeh condition: ripe (A) and start to rot (B).

\subsection{Ultra Violet Spectrum}

The ethanol extracts were scanned at ultra violet (UV) wavelength (200-400 nm). There was a similarity spectral pattern among genistein, soybean extract and tempeh extract (Figure 5). They have UV spectral characteristic of isoflavones. 


\section{Overlay Spectrum Graph}

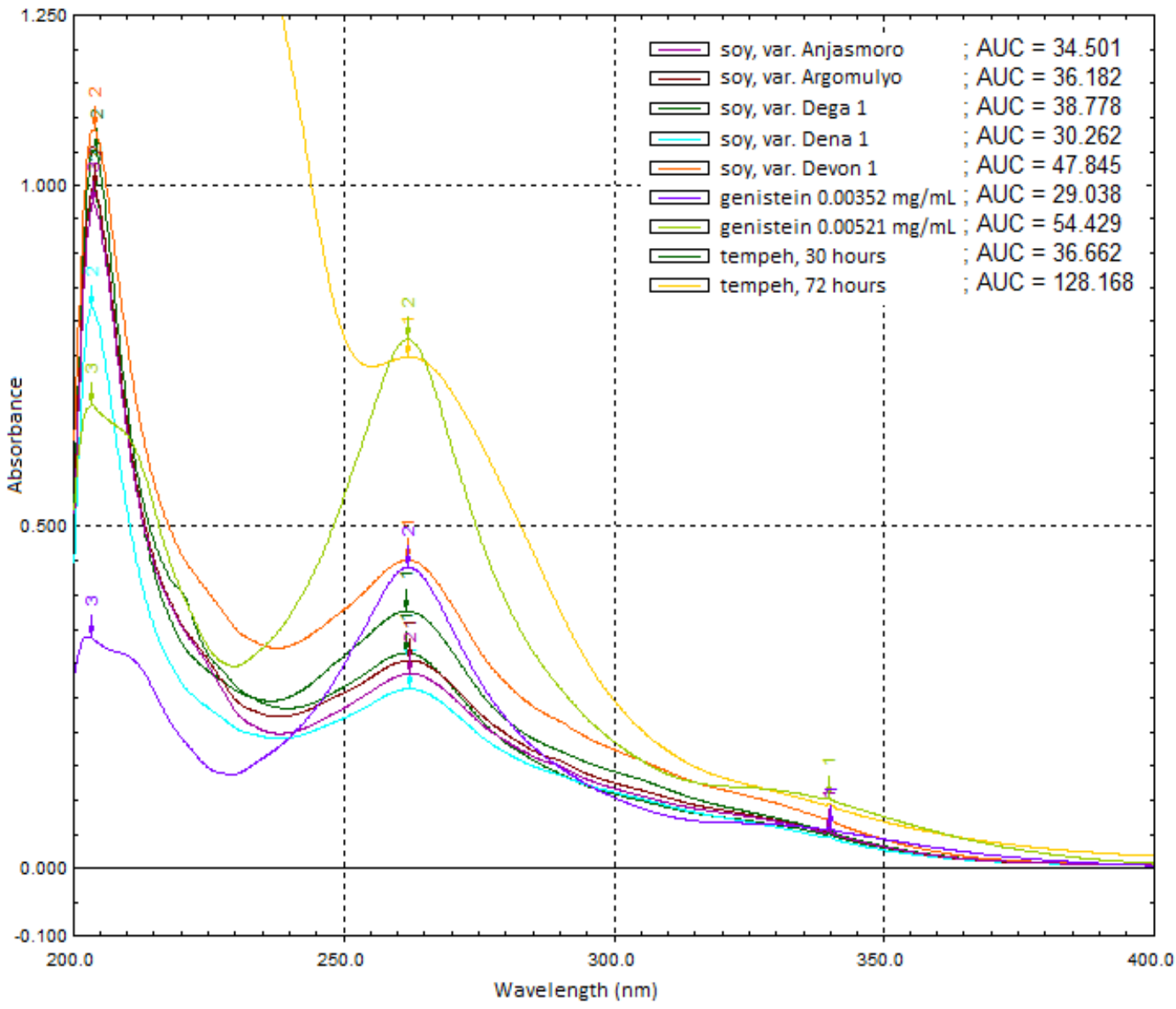

Figure 5. Overlay Uv-spectrum of soybean extract, tempeh extract, and genistein. Area under the curve (AUC) were counted manually from the spectrum, using trapezoid method.

\subsection{Total Isoflavones of Tempeh}

The total isoflavones content in tempeh were change along the fermentation time (Table 2). The highest level of isoflavones was in the fermentation time of 96 hours, but the tempeh was not suitable for consumption because the decay began to occur at that time. The total isoflavones content of tempeh at the $72^{\text {nd }}$ hour was no significant difference to the $96^{\text {th }}$ hour fermentation time and the condition was still very good.

Table 2. Total isoflavones in tempeh at various fermentation time at condition $\mathrm{b}\left(27 \pm 0.5^{\circ} \mathrm{C}\right)$

\begin{tabular}{ccc}
\hline $\begin{array}{c}\text { Fermentation } \\
\text { Time (hours) }\end{array}$ & $\begin{array}{c}\text { Isoflavon content } \\
(\% \mathbf{~ w} / \mathbf{w})\end{array}$ & Rank \\
\hline 0 & $0.034 \pm 0.0009^{\mathrm{a}}$ & 15 \\
6 & $0.035 \pm 0.0004^{\mathrm{a}}$ & 14 \\
12 & $0.032 \pm 0.0003^{\mathrm{a}}$ & 17 \\
18 & $0.033 \pm 0.0005^{\mathrm{a}}$ & 16 \\
24 & $0.043 \pm 0.0002^{\mathrm{ab}}$ & 12 \\
30 & $0.037 \pm 0.0003^{\mathrm{a}}$ & 13 \\
36 & $0.067 \pm 0.0242^{\mathrm{de}}$ & 9 \\
42 & $0.052 \pm 0.0004^{\mathrm{bc}}$ & 11 \\
48 & $0.057 \pm 0.0043^{\mathrm{cd}}$ & 10 \\
54 & $0.070 \pm 0.0027^{\mathrm{e}}$ & 7 \\
60 & $0.077 \pm 0.0019^{\mathrm{e}}$ & 6 \\
66 & $0.078 \pm 0.0014^{\mathrm{ef}}$ & 4
\end{tabular}




$\begin{array}{lcc}\mathbf{7 2} & \mathbf{0 . 0 8 9} \pm \mathbf{0 . 0 1 2 8} \mathbf{f g}^{\mathrm{fg}} & \mathbf{2}^{* *} \\ 78 & 0.070 \pm 0.0013^{\mathrm{e}} & 8 \\ 84 & 0.078 \pm 0.0012^{\mathrm{e}} & 5 \\ 90 & 0.079 \pm 0.0013^{\mathrm{f}} & 3 \\ 96 & 0.093 \pm 0.0051^{\mathrm{g}} & 1\end{array}$

* Means from three determinations \pm standard deviation followed by the same uppercase letter in the same column do not differ by the LSD-test at $5 \%$ significance; ${ }^{* *}$ selected fermentation time.

\section{Discussion}

\subsection{Selection of Soybean Varieties as Raw Material for Making Tempeh}

Five varieties of soybean seeds were selected, namely: Devon 1, Dena 1, Dega 1, Anjasmoro, and Argomulyo. Farmers commonly cultivate those varieties and use them as raw material for making tempeh and tofu. The soybean seeds were very good quality and certified by BALITKABI, Malang. Soy phytonutrients that are reported mainly contribute to memory ability are isoflavones, especially genistein and daidzein, through their role as phytoestrogens [7] and antioxidant [18]; [19]. Good quality of tempeh should be prepared start from the selection of good soybean seeds. Therefore, the first step was to determine the total isoflavones content in soybean seeds of the 5 varieties. This research show that variety of Devon 1 had the highest content of isoflavones, about $0.112 \%$ (Table 1). It was in line with the earlier researchers [10]; [12]. Soybean seeds of Devon 1 then proceed to get tempeh with high content of isoflavones.

\subsection{Process of Making Soybean Tempeh}

Several steps in the process of making tempeh will reduce the isoflavones content. At the step of first boiling for 30 minutes, soybean seeds would be softer and cause easier to peel the seed coat. Heating of course, causes the solubility of isoflavone glycosides in the cooking water. Grounding to break the seeds and separate husks were the next step. At these steps, some of the seeds would split into several pieces, even in the form of quite small pieces. This would further increase the contact surface area between seed pulp and water during soaking step. The next step was soak the soybean seeds for 12 hours so the seeds become softer and reduces the $\mathrm{pH}$ value. Soaking was not affect the carbohydrate and polyphenol content, but decrease the protein and increase the lipid content in soybean seeds [20]. This step was sure cause some of the isoflavone glycosides dissolve in the soaking water. It was physically observed that the immersion water become yellowish due to the dissolution of some isoflavone glycosides. The second boiling was carried out for 30 minutes as well. In this step, it was certain that some of the isoflavone glycosides dissolve again in the cooking water. This of course reduce the isoflavones content in the seeds again. The last step of tempeh production was fermentation after mixing soybean seeds with tempeh starter (culture of Rhizopus oligosporus mold). Finally, the total isoflavones level of Devon 1 seeds (Table 1) would decrease about $20 \%$ when it has become tempeh in 72 hour of fermentation (Table 2). During the fermentation process, the $\beta$-glikosidase enzyme from $R$. oligosporus was hydrolyze isoflavone glycosides to be free isoflavones (isoflavone aglycones). This hydrolysis process has been described by several researchers [21]; [22]. Isoflavone glycosides also can be hydrolyzed in the digestive tract [23], but it certainly takes a while and may not be perfectly. In the form of tempeh, most of the isoflavone glycosides have been hydrolyzed into isoflavone aglycones [22]. This last step is very important, because isoflavone glycosides hydrolyzed to be aglycone isoflavones.

Isoflavone glycosides are not absorbed in the adult people, while the aglycons absorbed [24], so by consuming tempeh, the benefits of isoflavones will be better obtained. Therefore, the loss of isoflavone glycosides during the process of making tempeh was compensated by the formation of free isoflavones that more active in human body. In tempeh, most of macromolecules form also have been hydrolyzed to be simpler, thus 
increasing the nutritional value of tempeh compared to soybeans without fermentation [25]. Rhizopus mold used in this tempeh preparation produced enzymes that able to hydrolyzed protein, lipid, and starch. Protein hydrolyzing increase the content of amino acids and low-molecular-weight peptides [26]. Hydrolyzing macromolecules of course cause the degradation of cells structure that make the tempeh softer and more desirable as food product.

\subsection{Fermentation Process}

Below $27^{\circ} \mathrm{C}$ the fermentation process will be slow, because low temperature inhibits the growth of Rhizopus mold. This condition would be detrimental because it allows the growth of contaminant bacteria faster than the growth of Rhizopus. In this study, when the fermentation temperature was maintained at $27 \pm 0.5{ }^{\circ} \mathrm{C}$ and given air circulation, the fermentation process run normally and the tempeh would be more durable.

At the other study, fermentation can also be carried out at a higher temperature, $30^{\circ} \mathrm{C}$ [27], also at $31^{\circ} \mathrm{C}$ with relative humidity of $92 \%$ [28] and both were no air circulation explained. Here in this research, fermentation at ambient temperature $\left(27-32^{\circ} \mathrm{C}\right)$ and without air circulation caused the tempeh too hot and rotted quickly (Figure 1). When inner temperature too hot, growth of Rhizopus is inhibited and mesophilic or thermophilic bacteria will grow quickly causes tempeh to rot. Nevertheless, at $30 \pm 0.5^{\circ} \mathrm{C}$ with air circulation (Figure 3), it produced a good tempeh. Air circulation was predicted able to distribute heat and moisture on the surface of tempeh. Thus, the air circulation on the surface of tempeh during the fermentation plays a very important role.

Increasing of fermentation temperature caused the inner peak temperature reached earlier. Although the fermentations were carried out at different temperature $\left(27 \pm 0.5^{\circ} \mathrm{C}\right.$ and $\left.30 \pm 0.5^{\circ} \mathrm{C}\right)$, the ripening time occurred at $31^{\text {st }}$ to $32^{\text {nd }}$ hour. In those conditions, the inner temperature of ripe tempeh was $32-33^{\circ} \mathrm{C}$. Without air circulation and fermented at ambient temperature (the rate was $28^{\circ} \mathrm{C}$ ), tempeh would ripe at $42^{\circ} \mathrm{C}$, although the ripening time remain at 33 hours, but the tempeh rotted quickly. Producing of good soybean tempeh needs optimum room temperature to minimized the energy consumption. This study show that the room temperature between $27 \pm 0.5^{\circ} \mathrm{C}$ to $30 \pm 0.5^{\circ} \mathrm{C}$ with air circulation would be suitable condition to produce good tempeh. Really, fermentation at $27 \pm 0.5^{\circ} \mathrm{C}$ (condition $\mathrm{b}$ ) was more suitable for tempeh production than fermented in $30 \pm 0.5^{\circ} \mathrm{C}$ (condition c). Fermentation at condition $b$, ripening occurred at the peak of inner temperature (Figure 1). It indicated that fermentation run smoothly and Rhizopus molds grew better than fermented at condition c. At condition c, inner peak temperature occurred before the tempeh ripening and higher than its ripening temperature. This condition was not good for Rhizopus growth. It can increase the risk of over heat and caused failure of fermentation. Based on this result, fermentation at condition b was chosen to produce tempeh with the standardization of total isoflavones content.

\subsection{Ultra Violet Spectrum}

UV scanning result show the similarity pattern of UV-spectrum of soybean extracts, tempeh extracts and genistein (Figure 5). This suggested that the main component in soybean extracts and tempeh extracts were isoflavones. There were different in quantity, indicated by their difference optical densities and area under the curve values (AUC200-400nm) (Figure 5). Table 1 presented the isoflavones content. The UV spectral of extracts can be used as a simple characteristic of soybean product.

\subsection{Selection of Fermentation Time}

Soybean seeds have good potency as material of functional food since the high content of isoflavones and capacity of antioxidant [1]. Soybean tempeh contains complete nutrients [2] and isoflavones that can improve memory [4]. With these reasons, tempeh 
has good chance to be processed as functional food for improve memory. As a functional food, tempeh should have a standard of total isoflavones content. Tempeh with high content of total isoflavones has to be designed from the start by choosing the best soybean variety. Based on this research, variety of Devon 1 was chosen to produce tempeh, because the total isoflavones content highest than four others (Table 1).

The series of processes for making tempeh cause the loss of some isoflavones, but these processes cannot be avoided. At the condition (b), tempeh at $72^{\text {nd }}$ hour of fermentation time, the isoflavones content of $0.089 \%$ was in the second place, not significantly different from the $96^{\text {th }}$ hour (Table 2). Tempeh at $72^{\text {nd }}$ hour of fermentation was still very good condition, very suitable for consumption. The decay process actually started around the $80^{\text {th }}$ hour (Figure 1) marked by the increase in tempeh temperature again. By these reasons, tempeh at $72^{\text {nd }}$ hour fermentation was chosen as a tempeh product standardized the total isoflavones content. It is interesting to investigate further, because the change in total isoflavones levels in tempeh really not linear with the increase of fermentation time.

\section{Conclusions}

The process of making tempeh will reduce the total isoflavones content by about $20 \%$. Good fermentation temperature for making soybean tempeh is around $27-30^{\circ} \mathrm{C}$. The ripening of tempeh is reached at the fermentation time between 31-32 hours, with the inner temperature around $32-33^{\circ} \mathrm{C}$. Tempeh production needs a good air circulation. The best condition of tempeh with highest isoflavones content is fermentation for 72 hours.

Author Contributions: Conceptualization, formal analysis, resources, and writing - original draft preparation, Y.D.; methodology, validation, E.L.; writing-review and editing, N.Y; writing-review, and supervision, S.W. All authors have read and agreed to the published version of the manuscript.

Funding: This research was funded by Kementerian Riset Teknologi Dan Pendidikan Tinggi Republik Indonesia I Lembaga Pengelola Dana Pendidikan (PRJ-4772/LPDP.3/2016).

Acknowledgments: The authors are grateful to the Kementerian Riset Teknologi Dan Pendidikan Tinggi Republik Indonesia; Research Institute for Assorted Beans and Tubers ('BALITKABI: Balai Penelitian Tanaman Aneka Kacang dan Umbi'), Malang, East Java, Indonesia for the supplied of soybean seeds.

Conflicts of Interest: The authors declare no conflict of interest. The funders had no role in the design of the study; in the collection, analyses, or interpretation of data; in the writing of the manuscript, or in the decision to publish the results.

\section{References}

1. Seo, W.D.; Kang, J.E.; Choi, S.W.; Lee, K.S.; Lee, M.J.; Park, K. Do; Lee, J.H. Comparison of nutritional components (isoflavone, protein, oil, and fatty acid) and antioxidant properties at the growth stage of different parts of soybean [Glycine max (L.) Merrill]. Food Sci. Biotechnol. 2017, 26, 339-347, doi:10.1007/s10068-017-0046-x.

2. Aldillah, R. Analisis Produksi Dan Konsumsi Kedelai Nasional; Sekolah pasca Sarjana Institut Pertanian Bogor: Bogor, 2014;

3. Marengo, M.; Akoto, H.; Zanoletti, M.; Carpen, A.; Buratti, S.; Benedetti, S.; Barbiroli, A.; Johnson, P.-N.; Sakyi-Dawson, E.; Saalia, F.; et al. Soybean-Enriched Snacks Based on African Rice. Foods 2016, 5, 38, doi:10.3390/foods5020038.

4. Bansal, N.; Parle, M. Effect of Soybean Supplementation on the Memory of Alprazolam-Induced Amnesic Mice. J. Pharm. Bioallied Sci. 2010, 2, 144-147, doi:10.4103/0975-7406.67001.

5. Georgetti, S.R.; Casagrande, R.; Souza, C.R.F.; Oliveira, W.P.; Fonseca, M.J. V Spray drying of the soybean extract: Effects on chemical properties and antioxidant activity. LWT - Food Sci. Technol. 2008, 41, 1521-1527, doi:10.1016/j.lwt.2007.09.001.

6. Arnone, B.; Patrono, E.; Gasbarri, A.; Pompili, A.; Arnone, B.; Cavicchio, A.; Patrono, E.; Amico, D.; Tavares, M.C.; Tomaz, C. Sex Steroid Hormone Estrogen and Cognition. Neurobiologia 2011, 74, 121-138. 
7. File, S.E.; Jarrett, N.; Fluck, E.; Duffy, R.; Casey, K.; Wiseman, H. Eating soya improves human memory. 2001, 430-436, doi:10.1007/s002130100845.

8. Lee, Y.B.; Lee, H.J.; Heon, S.S. Soy isoflavones and cognitive function. J. Nutr. Biochem. 2005, 16, 641-649, doi:10.1016/j.jnutbio.2005.06.010.

9. Hong, Y.; Gui-fang, J.I.N.; Dong-dong, R.E.N.; Si-jing, L.U.O.; Tian-hong, Z. Neuro-protective Mechanism of Isoflavones on Senescence-accelerated Mice. Chin. J. Nat. Med. 2010, 8, 280-284, doi:10.1016/S1875-5364(10)60035-0.

10. Liu, K. Soybeans as Functional Foods Editor; Liu, K. (University of M.C., Ed.; AOC Press: USA, $2004 ;$ ISBN 1893997332.

11. Rostagno, M.A.; Villares, A.; Guillamón, E.; García-lafuente, A.; Martínez, J.A. Sample Preparation for The Analysis of Isoflavones From Soybeans and Soy Foods. J. Chromatogr. A 2009, 1216, 2-29, doi:10.1016/j.chroma.2008.11.035.

12. Huang, M.; Liu, D. Thin Layer Chromatography Densitometric Determination of Soybean Isoflavones in Wild Soybean ( Glycine soja ) Seeds. Asian J. Chem 2012, 24, 1322-1324.

13. McCue, P.P.; Shetty, K. Phenolic antioxidant mobilization during yogurt production from soymilk using Kefir cultures. J. Proc. Bio. 2005, 40, 1791-1797, doi:10.1016/j.procbio.2004.06.067.

14. Gunawan-Puteri, M.D.P.T.; Hassanein, T.R.; Prabawati, E.K.; Wijaya, C.H.; Mutukumira, A.N. Sensory Characteristics of Seasoning Powders from Overripe Tempeh, a Solid State Fermented Soybean. Procedia Chem. 2015, 14, 263-269, doi:10.1016/j.proche.2015.03.037.

15. Ferreira, M.P.; de Oliveira, M.C.N.; Mandarino, J.M.G.; da Silva, J.B.; Ida, E.I.; Carrão-Panizzi, M.C. Changes in the isoflavone profile and in the chemical composition of tempeh during processing and refrigeration. Pesqui. Agropecu. Bras. 2011, 46, 1555-1561, doi:10.1590/S0100-204X2011001100018.

16. Iskandar, Y.M.; Priatni, S. Isoflavones Aglicone of Tempe Malang Fried Slices. Indones. J. Chem. 2010, 8, 437-442, doi:10.22146/ijc.21602.

17. Santoso Teknologi Pengolahan Kedelai: Teori dan Praktek; Fakultas Pertanian Universitas Widyagama Malang, 2005;

18. Rice-Evans, C.A.; Miller, N.J.; Paganga, G. Structure-antioxidant activity relationships of flavonoids and phenolic acids. Free Radic. Biol. Med. 1996, 20, 933-956, doi:10.1016/0891-5849(95)02227-9.

19. Heim, K.E.; Tagliaferro, A.R.; Bobilya, D.J. Flavonoid antioxidants: Chemistry, metabolism and structure-activity relationships. J. Nutr. Biochem. 2002, 13, 572-584, doi:10.1016/S0955-2863(02)00208-5.

20. Agume, A.; Njintang, N.; Mbofung, C. Effect of Soaking and Roasting on the Physicochemical and Pasting Properties of Soybean Flour. Foods 2017, 6, 12, doi:10.3390/foods6020012.

21. da Silva, L.H.; Celeghini, R.M.S.; Chang, Y.K. Effect of the fermentation of whole soybean flour on the conversion of isoflavones from glycosides to aglycones. Food Chem. 2011, 128, 640-644, doi:10.1016/j.foodchem.2011.03.079.

22. Borges, C.; Carrão-Panizzi, M.; Mandarino, J.; Bonifácio da Silva, J.; Benedetti, S.; Ida, E. Contents and bioconversion of $\beta$ glycoside isoflavones to aglycones in the processing conditions of soybean tempeh. Pesq. agropec. bras. 2016, 51, 271-279, doi:10.1590/S0100-204X2016000300009.

23. Day, A.J.; Dupont, M.S.; Ridley, S.; Rhodes, M.; Rhodes, M.J.C.; Morgan, M.R.A.; Y, G.W. Deglycosylation of flavonoid and iso flavonoid glycosides by human small intestine and liver B-glucosidase activity. FEBS 1998, 436, 71-75.

24. Setchell, K.D.R.; Brown, N.M.; Zimmer-Nechemias, L.; Brashear, W.T.; Wolfe, B.E.; Kirschner, A.S.; Heubi, J.E. Evidence for lack of absorption of soy isoflavone glycosides in humans, supporting the crucial role of intestinal metabolism for bioavailability. Am. J. Clin. Nutr. 2002, 76, 447-453, doi:10.1093/ajcn/76.2.447.

25. Aryanta, W.R. Traditional Fermented Foods in Indonesia. Japanese J. Lact. Acid Bact. 2000, 10, 90-102, doi:10.4109/jslab1997.10.90.

26. Handoyo, T.; Morita, N. Structural and functional properties of fermented soybean (Tempeh) by using rhizopus oligosporus. Int. J. Food Prop. 2006, 9, 347-355, doi:10.1080/10942910500224746.

27. Vital, R.J.; Bassinello, P.Z.; Cruz, Q.A.; Carvalho, R.N.; De Paiva, J.C.M.; Colombo, A.O. Production, quality, and 
acceptance of tempeh and white bean tempeh burgers. Foods 2018, 7, doi:10.3390/foods7090136.

28. Taylor, J.; Ahmed, I.A.M.; Al-Juhaimi, F.Y.; Bekhit, A.E.D.A. Consumers' perceptions and sensory properties of beef patty analogues. Foods 2020, 9, 1-14, doi:10.3390/foods9010063. 